\title{
Peran Tikus Sebagai Reservoir Leptospira di Tiga Ekosistem di Kabupaten Bantul, Yogyakarta
}

\author{
ROLE OF RATS IN LEPTOSPIROSIS TRANSMISSION \\ IN THREE TYPES ECOSISTEM IN BANTUL DISTRICT, YOGYAKARTA
}

\author{
Arum Sih Joharina*, Aryani Pujiyanti, Arief Nugroho, Ika Martiningsih, dan Farida Dwi Handayani \\ *Balai Besar Penelitian dan Pengembangan Vektor dan Reservoir Penyakit \\ J1. Hasanudin No.123, Mangunsari, Kec. Sidomukti, Kota Salatiga, Jawa Tengah 50721 \\ *Email:joharina.as@gmail.com
}

Submitted:02-07-2019, Revised : 16-08-2019, Revised : 24-08-2019, Accepted : 28-08-2019

\begin{abstract}
Bantul is one of leptospirosis endemic areas which has been reported the cases every year and the presence of rats is an important risk factor relating to leptospirosis incidence in Bantul. Therefore, the role of rats as reservoir was examined in three types of ecosystems: forest, non-forest, and coastal ecosystems. Rat trapping was carried out using 100 single livetraps which were distributed in 9 locations: 2 points in the forest, 5 points in the non-forest, and 2 points in the coastal ecosystem. The rats were identified and their kidneys were collected and preserved in 70\% alcohol medium. Leptospira were detected in the kidney by using PCR method. A number of 196 rats were obtained during the study. Most of them were commensal rats obtained from settlements ecosystems. Rattus tanezumi was the dominant species in the three ecosystems, but the highest infection rate of leptospira pathogen was in R.norvegicus. Coastal ecosystems were contained more infected rats, where the main habitat were mangrove forests. Based on these results, rats have great potency in leptospirosis transmission in Bantul, especially in settlements and coastal areas although leptospirosis cases were reported rarely in study area. Nonetheless, awareness of transmission should be disseminated since the presence of pathogenic leptospira in rats is very high.
\end{abstract}

Keywords: leptospirosis, rat, reservoir, ecosystem, Bantul

\begin{abstract}
Abstrak
Kabupaten Bantul merupakan salah satu daerah endemis leptospirosis yang sejak lama melaporkan kasus ini setiap tahunnya dan keberadaan tikus merupakan faktor risiko penting yang mempengaruhi kejadian leptospirosis di Kabupaten Bantul. Oleh karena itu peranan tikus sebagai hewan reservoir diteliti di tiga jenis ekosistem yaitu ekosistem hutan, non-hutan, dan pesisir. Penangkapan tikus dilakukan menggunakan perangkap tunggal sebanyak 100 buah yang disebar di 9 titik lokasi, meliputi dua titik di ekosistem hutan, lima titik di ekosistem non-hutan, dan dua titik di ekosistem pesisir. Tikus tertangkap diidentifikasi kemudian organ ginjalnya dikoleksi dan diawetkan dalam medium alkohol $70 \%$. Bakteri leptospira dideteksi pada specimen ginjal dengan metode PCR dari total 196 tikus diperoleh selama penelitian. Sebagian besar tikus diperoleh dari ekosistem dekat pemukiman dan semuanya merupakan tikus komensal. Rattus tanezumi merupakan spesies dominan di ketiga ekosistem, namun persentase infeksi leptospira patogen paling tinggi terdapat pada $R$. norvegicus. Ekosistem pesisir mengandung tikus terinfeksi leptospira patogenik paling tinggi, dengan habitat utama hutan mangrove. Berdasarkan hasil ini maka tikus berpotensi besar menularkan leptospirosis di Kabupaten Bantul, terutama di daerah pemukiman dan pesisir. Meskipun kasus leptospirosis di daerah penelitian sedikit sekali dilaporkan, namun kewaspadaan terhadap penularan perlu dilakukan sedini mungkin karena leptospira patogenik yang terkandung dalam tikus tergolong tinggi.
\end{abstract}

Kata kunci: leptospirosis, tikus, reservoir, ekosistem, Bantul 


\section{PENDAHULUAN}

Leptospirosis merupakan penyakit
zoonosis yang disebabkan oleh bakteri Spirochaeta dari genus Leptospira. Bakteri ini memperbanyak diri di tubuh inang reservoir dimana sebagian besar adalah hewan mamalial dan dikeluarkan bersama sekresi urine.$^{1,2}$ Air yang tercemar oleh urine hewan reservoir menjadi media penularan bakteri leptospira patogen. Leptospira menginfeksi manusia atau hewan lain dengan infiltrasi melalui luka terbuka atau selaput lendir. Tingkat keparahan yang ditimbulkan oleh Leptospira patogenik sangat bervariasi mulai dari asimtomatik sampai menyebabkan kegagalan organ dan komplikasi yang mengakibatkan kematian jika terlambat diobati. ${ }^{1}$ Penularan leptospirosis ditentukan oleh keberadaan agent bakteri leptospira patogen, adanya inang reservoir, juga dipengaruhi oleh kondisi lingkungan yang mendukung perkembangan bakteri leptospira maupun reservoir, serta perilaku manusia. ${ }^{3,4}$

Tikus bertindak sebagai reservoir utama bakteri Leptospira spp. ${ }^{5}$ Berbagai spesies leptospira patogenik berhasil dideteksi dalam ginjal maupun urine tikus. Antibodi terhadap serovar-serovar leptospira juga ditemukan dalam serum tikus. ${ }^{6}$ Meskipun tubuhnya menjadi tempat hidup leptospira patogen, tikus mampu bertahan hidup dan tidak menampakkan gejala klinis yang signifikan, berbeda dengan mamalia lain misalnya anjing atau sapi. ${ }^{4}$

Persebaran populasi tikus terdapat hampir di setiap ekosistem sehingga turut mendukung peranannya sebagai reservoir. "Ekologi tikus merupakan determinan penting dalam dinamika penularan patogen zoonotik dalam suatu populasi tikus maupun pada manusia. ${ }^{7}$ Tiap spesies tikus memiliki kecenderungan untuk menyukai suatu jenis habitat. Terdapat spesies tikus asli (endemis) yang hidup dengan ciri habitat tertentu saja, namun terdapat juga beberapa spesies yang besifat komensal dan invasif. Rattus rattus, R.norvegicus, dan R.exulans merupakan spesies yang menempati $80 \%$ lahan dari spesies tikus endemis lainnya. ${ }^{8}$ Kepadatan populasi tiap spesies tikus ini dapat berfluktuasi tergantung pada kondisi lingkungannya ${ }^{9-11}$, sehingga turut berpengaruh pada transfer patogen yang dibawanya.

Kabupaten Bantul termasuk daerah di Provinsi Daerah Istimewa Yogyakarta (DIY) dengan endemisitas tinggi leptospirosis. Insidensi terjadi setiap tahun dengan persebaran hampir merata di semua kecamatan (unpublished data). Faktor risiko penularan leptospirosis paling dominan telah diteliti di wilayah DIY termasuk di Kabupaten Bantul, yaitu keberadaan tikus dan profesi sebagai petani. ${ }^{12,13}$ Meskipun keberadaan tikus merupakan faktor risiko paling penting, namun penelitian yang ada belum cukup menggambarkan kondisi di setiap tipe ekosistem. Makalah ini bertujuan mengetahui peran tikus dalam penularan leptospirosis di ekosistem hutan, non-hutan, dan pesisir Kabupaten Bantul melalui persentase infeksi leptospira patogenik pada tikus di tiga tipe ekosistem tersebut.

\section{BAHAN DAN METODE}

Data penelitian berasal dari Riset Nasional Rikhus Vektora tahun 2017 yang salah satu lokasinya di Provinsi DIY. Pengumpulan data lapangan dilaksanakan pada bulan Mei 2017.

\section{Penentuan titik lokasi dan habitat}

Penangkapan tikus dilakukan pada sembilan titik lokasi dengan pembagian berdasar atas ekosistem, yaitu dua titik di ekosistem hutan (titik 1 dan 2), lima titik di ekosistem non-hutan (titik 3-7), dan dua titik di ekosistem pesisir (titik 8 dan 9). Ekosistem hutan berdasarkan UU No.41 Th.1999 didefinisikan sebagai bentangan dengan vegetasi tumbuhan sedang hingga tinggi, kanopi rapat sehingga menutup sebagian besar permukaan tanah. Ekosistem pesisir dalam penelitian ini merupakan desa/kelurahan yang berbatasan langsung dengan garis pesisir, sedangkan ekosistem non-hutan adalah ekosistem yang tidak termasuk keduanya. Ekosistem nonhutan diambil lebih banyak karena proporsinya di Kabupaten Bantul paling besar. Selain itu titik pengambilan sampel juga mewakili lokasi dekat dengan pemukiman (titik 1, 3, 5, 6, 7, dan 8) dan lokasi jauh dari pemukiman (titik 2, 4, dan 9). Definisi operasional jauh dari pemukiman yaitu jika titik ordinat tersebut berjarak radius $>3 \mathrm{~km}$ dari pemukiman terdekat. Tiap-tiap titik dibagi ke dalam habitat-habitat yang ada pada daerah tersebut

Pada tiap titik lokasi dilakukan penangkapan tikus sesuai Cunningham and P.J Moors (1999) dengan menyebarkan 100 perangkap tunggal (single live trap) dengan umpan berupa kelapa bakar. ${ }^{14}$ Khusus untuk titik dekat dengan 
pemukiman (6 titik), pemasangan perangkap dibagi menjadi dua lokasi yaitu 50 ditempatkan didalam rumah/bangunan, dan 50 ditempatkan di luar rumah/bangunan. Jarak pemasangan antar perangkap minimal $10 \mathrm{~m}$ untuk habitat luar rumah, sedangkan untuk habitat berupa rumah perangkap dipasang 2 buah tiap rumah di tempat-tempat yang sering dilalui tikus. Setiap perangkap diambil titik koordinatnya dengan GPS. Pemasangan perangkap dilakukan pada sore hari (sekitar pukul 15.0018.00), dan dipanen pada pagi harinya (pukul 06.00-07.00). Lama pemasangan perangkap pada satu titik lokasi adalah 2 kali selama 2 malam berturut-turut. Tikus tertangkap diidentifikasi spesiesnya menggunakan kunci identifikasi tikus Indo Malaya. ${ }^{15}$ Tikus dianestesi menggunakan ketamine-xilazine (4:3) dengan dosis ketamine 70$100 \mathrm{mg} / \mathrm{kg}$ berat badan dan dosis xilazine $2 \mathrm{mg} / \mathrm{kg}$ BB. Kedua Organ ginjal diambil dan dimasukkan ke dalam botol kaca berisi alkohol 70\% untuk proses pemeriksaan leptospira patogen.

\section{Pemeriksaan laboratorium Isolasi DNA dan PCR}

Isolasi DNA untuk deteksi leptopsira patogen, dilakukan terhadap spesimen ginjal tikus. Ginjal dibilas dengan akuades steril, dipotong kurang lebih $25 \mathrm{mg}$ di bagian tubulus renalis, dimasukkan ke dalam vial $1,5 \mathrm{ml}$ steril. Isolasi DNA dari jaringan ginjal menggunakan kit isolasi Purelink Genomic DNA Mini Kit (Invitrogen, USA). Produk DNA dielusi sebanyak $50 \mu \mathrm{l}$.

Deteksi leptospira patogen dilakukan dengan amplifikasi segmen gen SecY menggunakan pasangan primer dengan urutan sbb: F- 5' ATGCCGATCATTTTTGCTTC 3' dan R- 5' CCGTCCCTTAATTTTAGCTTCTTC 3' 16. Primer ini mengamplifikasi produk sebesar 549 bp. Amplifikasi DNA dari jaringan ginjal dilakukan dengan menggunakan Go Taq Green Master Mix (Promega, USA). Total reaksi adalah $25 \mu \mathrm{l}$, terdiri dari $5 \mu \mathrm{l}$ DNA, $12.5 \mu \mathrm{l} 2 \mathrm{x}$ Master Mix, $2 \mu \mathrm{l}(400 \mathrm{nM})$ primer, dan $3.5 \mu 1$ nuclease free water. Amplifikasi dijalankan dengan termocycler SimpliAmp Thermal Cycler, Applied Biosystem dengan suhu denaturasi awal $95^{\circ} \mathrm{C}$ selama 5 menit, 35 siklus denaturasi pada suhu $94^{\circ} \mathrm{C}$ selama 30 detik, annealing $58^{\circ} \mathrm{C}$ selama 30 detik, dan ekstensi $72^{\circ} \mathrm{C}$ selama 1 menit. Ekstensi akhir ditambahkan pada $72^{\circ} \mathrm{C}$ selama 7 menit dan inkubasi pada $4^{\circ} \mathrm{C}$. Produk amplifikasi dielektroforesis dalam gel agarose $2 \%$.

\section{Data Sekunder}

Data sekunder pada artikel ini meliputi data kasus leptospirosis per desa/kelurahan Kabupaten Bantul dan data tata guna lahan Kabupaten Bantul tahun 2015. Kasus leptospirosis diperoleh dari Dinas Kesehatan Kabupaten Bantul dan dicatat dalam rentang tahun 2015-2016 dengan data kasus per desa, sedangkan penentuan desa yang masuk ke kategori ekosistem hutan, non-hutan, atau pesisir didasarkan pada data tata guna lahan yang diperoleh dari Peta Rupa Bumi Indonesia, BIG tahun 2015.

\section{HASIL}

Kabupaten Bantul secara administratif terbagi atas 17 kecamatan dan 75 desa/kelurahan. Berdasarkan kriteria penentuan titik lokasi pengambilan sampel, diperoleh sembilan desa yang mewakili 3 ekosistem. Daftar nama desa pada tiap ekosistem tertera pada Tabel 1. Insidensi leptospirosis di Kabupaten Bantul selama rentang waktu 2015-2016 tercatat dengan range nol sampai sembilan kasus per desa/kelurahan. Jumlah kasus per desa/kelurahan dibagi menjadi 3 zonasi, sebagaimana ditunjukkan dalam peta (Gambar 1). Dari sembilan lokasi penelitian, hanya tiga desa yang tercatat melaporkan kasus leptospirosis tahun 2015-2016. Dua desa termasuk kategori ekosistem non-hutan dan satu desa termasuk kategori ekosistem pesisir (Tabel 1).

Tikus yang berhasil diperoleh seluruhnya berjumlah 196 ekor yang tersebar pada sembilan lokasi penelitian. Tikus tertangkap terdiri atas delapan spesies (Tabel 2). Rattus tanezumi mendominasi hampir seluruh titik dekat dengan pemukiman(titik 1,3,5,6,7, dan 9) baik di ekosistem hutan, non-hutan maupun pesisir. Jumlah perolehan $R$. tanezumi hampir dua setengah kali dari R.tiomanicus dan R.norvegicus, namun dari hasil pemeriksaan bakteri leptospira patogenik, persentase infeksi R.tanezumi jauh lebih rendah dari dua spesies tersebut. Rattus tiomanicus dan R.norvegicus memiliki total proporsi yang kurang lebih sama, perbedaannya terdapat pada lokasi ditemukannya bahwa R.tiomanicus hampir seluruhnya ditemukan di titik jauh dari pemukiman, sebaliknya R.norvegicus hanya ditemukan di titik dekat dengan pemukiman. Rattus norvegicus memiliki persentase infeksi leptospira patogenik tertinggi yang terdapat pada ekosistem non-hutan dan pesisir dekat dengan 
pemukiman. Rattus tiomancus juga memiliki persentase infeksi leptospira patogen tinggi, namun hampir semuanya terdapat di ekosistem pesisir.

Berdasarkan ekosistemnya, perolehan tikus di ekosistem hutan dan pesisir memiliki rata-rata hampir sama, sedangkan perolehan tikus di ekosistem non-hutan memiliki rata-rata lebih rendah. Namun terdapat perbedaan yang mencolok dimana perolehan tikus di titik dekat dengan pemukiman jauh lebih tinggi dari titik jauh dari pemukiman. Sementara berdasarkan hasil pemeriksaan PCR leptospira patogenik, ekosistem pesisir memiliki persentase infeksi tertinggi dan ekosistem hutan yang terendah.

Hasil survei habitat di tiap titik lokasi diperoleh total enam jenis habitat, meliputi habitat hutan sekunder, pemukiman/rumah, kebun, sawah, pantai, dan hutan mangrove (Tabel 3). Habitat dengan jumlah tangkapan tikus tertinggi adalah habitat rumah/pemukiman, namun persentase tikus terinfeksi leptospira tertinggi ditemukan di habitat hutan mangrove (Tabel 3).

\section{Tabel 1. Daerah Lokasi Pengumpulan Data}

\begin{tabular}{lllll}
\hline Titik & \multicolumn{1}{c}{ Jenis ekosistem } & Jarak dari pemukiman & \multicolumn{1}{c}{ Nama daerah } & $\begin{array}{c}\text { Kasus leptospirosis } \\
(\mathbf{2 0 1 7 )}\end{array}$ \\
\hline 1 & Hutan & Dekat pemukiman & Desa Wukirsari, Kecamatan Imogiri & 0 \\
2 & Hutan & Jauh pemukiman & Desa Wukirsari, Kecamatan Imogiri & 0 \\
3 & Non hutan & Dekat pemukiman & Desa Bangunharjo, Kecamatan Sewon & 3 \\
4 & Non hutan & Dekat pemukiman & Desa Potorono, Kecamatan Banguntapan & 0 \\
5 & Non hutan & Dekat pemukiman & Desa Potorono, Kecamatan Banguntapan & 0 \\
6 & Non hutan & Dekat pemukiman & Desa Potorono, Kecamatan Banguntapan & 0 \\
7 & Non hutan & Jauh pemukiman & Desa Trimulyo, Kecamatan Jetis & 2 \\
8 & Pesisir & Dekat pemukiman & Desa Parangtritis, Kecamatan Kretek & 1 \\
9 & Pesisir & Jauh pemukiman & Desa Tirtohargo, Kecamatan Kretek & 0 \\
\hline
\end{tabular}

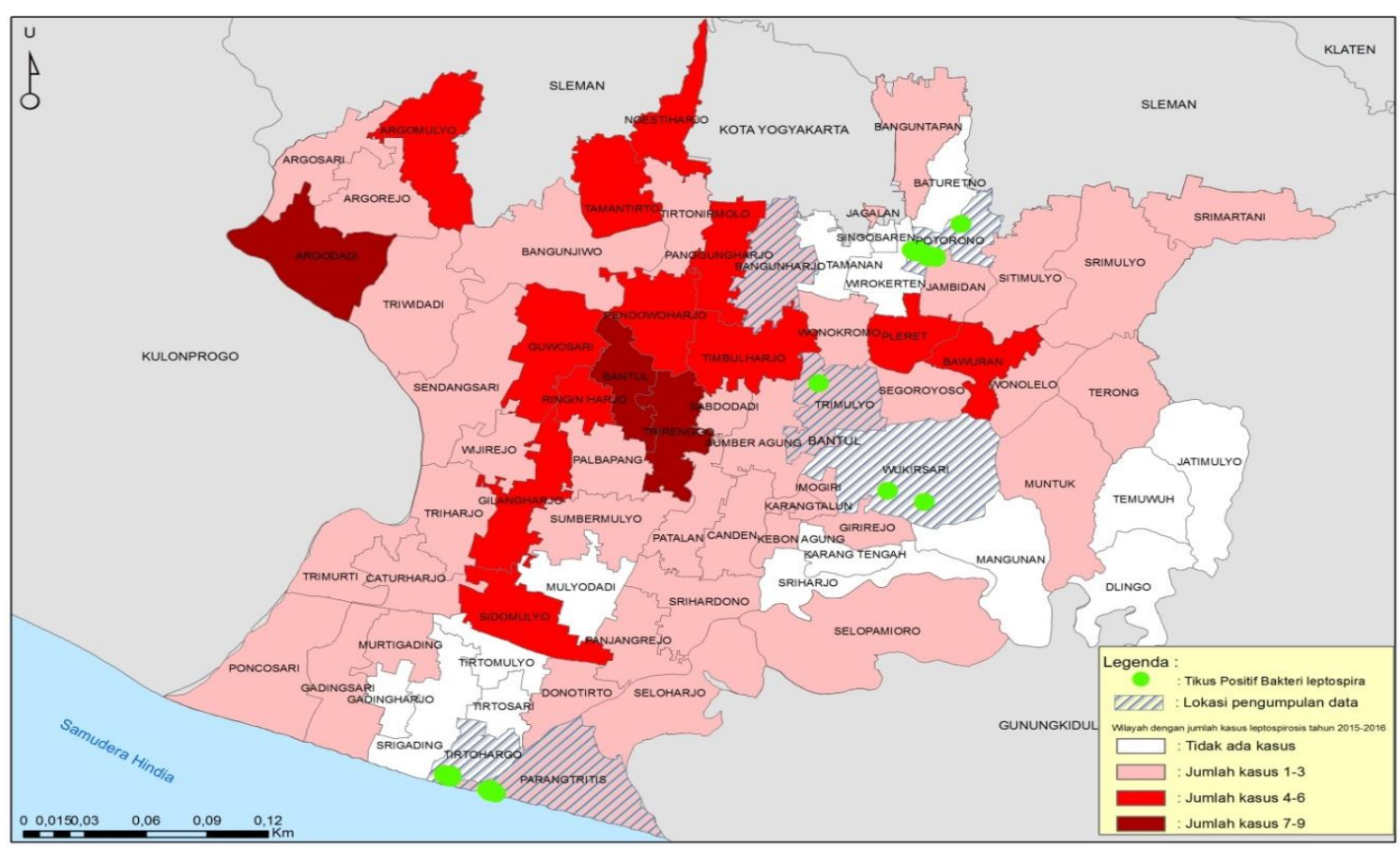

Gambar 1. Peta persebaran kasus leptospirosis dan tikus positif Leptospira patogen di Kabupaten Bantul

Keterangan: Warna merah muda - merah tua menunjukkan intensitas banyaknya kasus di tahun 2015-2016. Warna merah muda: jumlah kasus 1-3, merah: 4-6, merah tua: 7-9, dan putih: tidak ada kasus di tahun tersebut. Simbol bulatan: titik dimana ditemukan tikus positif Leptospira patogen. 
Tabel 2. Jumlah Tikus Terinfeksi Leptospira Patogen dan Tikus Tertangkap Menurut Spesies Tikus di Sembilan Titik Lokasi

\begin{tabular}{|c|c|c|c|c|c|c|c|c|c|c|c|}
\hline \multirow{3}{*}{ Jenis Tikus } & \multicolumn{2}{|c|}{ Hutan } & \multirow{2}{*}{\multicolumn{4}{|c|}{$\begin{array}{c}\text { Non-hutan } \\
\text { Titik lokasi }\end{array}$}} & \multicolumn{3}{|c|}{ Pesisir } & \multirow{3}{*}{$\begin{array}{c}\text { Jml positif Leptospira } \\
\text { patogen/ Jml tikus } \\
\text { tertangkap }(\mathbf{n} / \mathbf{N})\end{array}$} & \multirow{3}{*}{$\begin{array}{c}\text { Persentase positif } \\
(\%)\end{array}$} \\
\hline & & & & & & & & & & & \\
\hline & 1 & 2 & 3 & 4 & 5 & 6 & 7 & 8 & 9 & & \\
\hline R. tanezumi & $1 / 34$ & $0 / 0$ & $0 / 11$ & $0 / 0$ & $2 / 21$ & $0 / 18$ & $6 / 10$ & $0 / 6$ & $0 / 0$ & $9 / 100$ & 9 \\
\hline R. tiomanicus & $0 / 0$ & $1 / 16$ & $0 / 0$ & $1 / 1$ & $0 / 0$ & $0 / 0$ & $0 / 0$ & $0 / 1$ & $11 / 24$ & $13 / 42$ & 31 \\
\hline R. norvegicus & $0 / 6$ & $0 / 0$ & $0 / 0$ & $0 / 0$ & $4 / 6$ & $1 / 3$ & $0 / 3$ & $12 / 22$ & $0 / 0$ & $17 / 40$ & 43 \\
\hline B. indica & $0 / 0$ & $0 / 0$ & $0 / 3$ & $0 / 0$ & $0 / 1$ & $0 / 1$ & $1 / 3$ & $0 / 1$ & $0 / 0$ & $1 / 9$ & 11 \\
\hline R. exulans & $0 / 1$ & $0 / 0$ & $0 / 0$ & $0 / 0$ & $0 / 1$ & $0 / 0$ & $0 / 0$ & $0 / 0$ & $0 / 0$ & $0 / 2$ & 0 \\
\hline Mus caroli & $0 / 0$ & $0 / 0$ & $0 / 0$ & $0 / 0$ & $0 / 0$ & $0 / 0$ & $0 / 0$ & $0 / 0$ & $0 / 1$ & $0 / 1$ & 0 \\
\hline B. bengalensis & $0 / 0$ & $0 / 0$ & $0 / 0$ & $0 / 0$ & $0 / 0$ & $0 / 0$ & $0 / 0$ & $0 / 1$ & $0 / 0$ & $0 / 1$ & 0 \\
\hline B. cf.indica & $0 / 0$ & $0 / 0$ & $0 / 0$ & $0 / 0$ & $0 / 1$ & $0 / 0$ & $0 / 0$ & $0 / 0$ & $0 / 0$ & $0 / 1$ & 0 \\
\hline Jumlah & $1 / 41$ & $1 / 16$ & $0 / 14$ & $1 / 1$ & $6 / 30$ & $1 / 22$ & $7 / 16$ & $12 / 31$ & $11 / 25$ & $40 / 196$ & 20,4 \\
\hline $\begin{array}{l}\text { Persentase } \\
\text { Infeksi }\end{array}$ & \multicolumn{3}{|c|}{$2 / 196=1 \%$} & \multicolumn{3}{|c|}{$15 / 196=37,5 \%$} & \multicolumn{3}{|c|}{$23 / 196=57,5 \%$} & & \\
\hline
\end{tabular}

Keterangan:Kolom kedua sampai kesepuluh menerangkan jumlah tikus positif leptospira patogenik per jumlah total tikus tertangkap pada tiap spesies. Titik lokasi 1-2 mewakili ekosistem hutan, titik 3-7 mewakili ekosistem non-hutan, dan titik 8-9 mewakili ekosistem pesisir. Baris terakhir menerangkan rata-rata persentase infeksi ekosistem hutan, non-hutan dan pesisir. $\mathrm{N}=$ jumlah total tikus tertangkap/ $\mathrm{n}=$ jumlah tikus positif leptospira.

Tabel 3. Jumlah Tikus Terinfeksi Leptospira Patogen dan Tikus Tertangkap di Sembilan Titik Lokasi

\begin{tabular}{|c|c|c|c|c|c|c|c|c|c|c|c|}
\hline \multirow{3}{*}{ Jenis Habitat } & & & & & on-hu & & & & & \multirow{3}{*}{$\begin{array}{c}\text { Jml tikus positif/jml } \\
\text { tikus tertangkap } \\
(\mathrm{n} / \mathrm{N})\end{array}$} & \multirow{3}{*}{$\begin{array}{c}\text { Persentase positif } \\
(\%)\end{array}$} \\
\hline & \multicolumn{9}{|c|}{ Titik lokasi } & & \\
\hline & 1 & 2 & 3 & 4 & 5 & 6 & 7 & 8 & 9 & & \\
\hline Mangrove & $0 / 0$ & $0 / 0$ & $0 / 0$ & $0 / 0$ & $0 / 0$ & $0 / 0$ & $0 / 0$ & $0 / 0$ & $11 / 20$ & $11 / 20$ & 55 \\
\hline Sawah & $0 / 0$ & $0 / 0$ & $0 / 1$ & $0 / 0$ & $1 / 10$ & $1 / 1$ & $2 / 4$ & $0 / 0$ & $0 / 0$ & $4 / 16$ & 25 \\
\hline Kebun & $0 / 0$ & $0 / 0$ & $0 / 3$ & $1 / 1$ & $0 / 0$ & $0 / 1$ & $0 / 0$ & $0 / 0$ & $0 / 0$ & $1 / 5$ & 20 \\
\hline Rumah/pemukiman & $1 / 39$ & $0 / 0$ & $0 / 10$ & $0 / 0$ & $5 / 20$ & $0 / 20$ & $5 / 12$ & $12 / 31$ & $0 / 0$ & $23 / 132$ & 17 \\
\hline Hutan sekunder & $0 / 2$ & $1 / 16$ & $0 / 0$ & $0 / 0$ & $0 / 0$ & $0 / 0$ & $0 / 0$ & $0 / 0$ & $0 / 0$ & $1 / 18$ & 6 \\
\hline Pantai & $0 / 0$ & $0 / 0$ & $0 / 0$ & $0 / 0$ & $0 / 0$ & $0 / 0$ & $0 / 0$ & $0 / 0$ & $0 / 5$ & $0 / 5$ & 0 \\
\hline Jumlah & & & & & & & & & & $40 / 196$ & 20,4 \\
\hline
\end{tabular}

Keterangan:Kolom kedua sampai kesepuluh menerangkan jumlah tikus positif leptospira patogenik per jumlah total tikus tertangkap pada tiap habitat. Titik lokasi 1-2 mewakili ekosistem hutan, titik 3-7 mewakili ekosistem non-hutan, dan titik 8-9 mewakili ekosistem pesisir.

\section{PEMBAHASAN}

Sembilan titik lokasi penelitian di Kabupaten Bantul menunjukkan keberadaan tikus terdapat merata di ketiga ekosistem. Titik dekat dengan pemukiman memiliki kepadatan relatif yang lebih tinggi dibandingkan dengan titik jauh dari pemukiman. Dari segi keragaman spesiesnya, baik lokasi dekat maupun jauh dari pemukiman tidak banyak perbedaan. Sebanyak delapan spesies yang ditemukan didominasi oleh tikus komensal yaitu R.tanezumi, R.tiomanicus dan R.norvegicus.
Ketiga spesies tersebut sering juga disebut tikus invasif, karena seringkali menginvasi spesies asli sehingga mengakibatkan penurunan populasi spesies asli/endemis di suatu habitat. ${ }^{10,17,18}$ Spesies silvatik tidak ditemukan dalam penelitian ini.

Rattus tanezumi merupakan spesies paling dominan yang ditemukan di ketiga ekosistem. Habitat alami R.tanezumi adalah lingkungan sekitar manusia, seringkali bersarang di bangunan/ rumah-rumah penduduk (seperti atap rumah, atas plafon, atau pipa-pipa). ${ }^{19}$ Ditemukannya R.tanezumi di area hutan, seperti halnya spesies 
komensal lainnya dapat disebabkan oleh banyak faktor diantaranya tekanan dari kepadatan populasi dalam satu spesies maupun kompetisi dengan spesies lain yang lebih dominan sehingga memaksanya bermigrasi. ${ }^{19}$ Selain itu, kondisi ekosistem hutan di Kabupaten Bantul lebih cenderung kepada hutan sekunder, dengan tingkat kerapatan vegetasi sedang, serta masih terdapat sedikit aktivitas perambahan oleh manusia. Jenis habitat ini diistilahkan oleh Banks et al. (2015) sebagai "bushland", yaitu vegetasi yang tidak dibudidayakan manusia, dan biasanya berisi spesies flora asli. Tipe habitat tersebut menurut Banks et al. (2015) masih dapat dipergunakan oleh tikus komensal sebagai sumber mencari makanan, dan memungkinkan tikus berpindah-pindah di antara dua tipe habitat yang sangat berbeda, yaitu habitat pemukiman dan hutan (bushland). ${ }^{18}$

Peran tikus sebagai reservoir leptospirosis salah satunya dibuktikan dengan persentase infeksi bakteri leptospira yang terkandung dalam ginjal tikus. Persentase infeksi leptospira patogen pada penelitian ini secara total $20,4 \%$ termasuk angka yang tinggi. Rattus norvegicus merupakan spesies dengan persentase paling tinggi (43\%), hampir lima kali dari R.tanezumi. Prevalensi bakteri leptospira patogenik dalam tubuh tikus dilaporkan di beberapa lokasi di Indonesia di antaranya di Kota Semarang 33,43\% pada R.norvegicus dan $13,69 \%$ pada R.tanezumi ${ }^{20}$, di daerah pelabuhan Kota Maumere memiliki prevalensi 4\%, hanya ditemukan pada R.norvegicus ${ }^{21}$ saja. Prevalensi leptospira patogenik pada R.norvegicus di dunia rata-rata pada kisaran $20-25 \%$, namun beberapa negara melaporkan persentase yang sangat tinggi, seperti di Kota Phnom Penh, Kamboja mencapai $49,1 \%{ }^{22}$ dan di Vancouver, Canada mencapai $66,7 \%{ }^{23}$

Prevalensi leptospira pada tikus dipengaruhi oleh beberapa faktor antara lain tipe lingkungan (habitat dan ketinggian tempat) 2,24 dan jenis kelamin. $^{2}$ Kemampuan berenang hewan reservoir dan temperatur minimal juga berkaitan dengan infeksi leptospira. ${ }^{9}$ Spesies tikus, menurut Costa (2015) tidak berpengaruh secara signifikan terhadap prevalensi leptospira, akan tetapi hasil berbeda disebutkan oleh Ikawati dkk (2012) bahwa spesies R.norvegicus memiliki risiko terhadap penularan leptospirosis 78 kali lebih tinggi, sedangkan R.tanezumi delapan kali lebih tinggi. ${ }^{24}$ Dalam hal ini, hasil penelitian ini menunjukkan kesamaan dengan hasil penelitian Ikawati dkk tersebut, bahwa spesies $R$. norvegicus memiliki potensi lebih tinggi sebagai reservoir leptospira dibandingkan R.tanezumi.

Berdasarkan ekosistemnya, pesisir memiliki persentase infeksi leptospira patogen yang paling tinggi, terkonsentrasi pada spesies R.tiomanicus dan jenis habitat mangrove. Sebuah studi yang mendukung temuan ini mengatakan bahwa habitat mangrove memiliki sumber makanan yang selalu tersedia sepanjang tahun sehingga kelimpahan fauna khususnya tikus selalu terjaga. ${ }^{10}$ Namun faktor salinitas yang selama ini dianggap menghambat pertumbuhan bakteri Leptospira spp juga sekaligus menjadi pertanyaan yaitu darimanakah bakteri ini didapatkan oleh tikus, dimanakah sumber penularannya?

Ekosistem non-hutan terdiri atas beberapa habitat yaitu rumah/pemukiman, pekarangan, sawah, dan kebun. Habitat rumah/pemukiman pada hasil penelitian merupakan habitat yang paling tinggi kepadatan relatifnya. Ini adalah hal yang umum karena tikus komensal telah sejak lama beradaptasi dan menjadi penghuni alami lingkungan dimana ada kehidupan manusia. ${ }^{18,25,26}$ Meskipun demikian, habitat yang lebih tinggi persentasenya terhadap infeksi leptospira patogenik bukan habitat rumah melainkan habitat sawah (dalam hal pekarangan masih dianggap lingkungan rumah). Hasil ini pun mendukung studi sebelumnya bahwa area pertanian merupakan faktor risiko utama di Kabupaten Bantul. ${ }^{13}$

Pada lokasi penelitian khususnya, dari sembilan lokasi, hanya terdapat 3 lokasi (desa) yang melaporkan kasus dari tahun 2015-2016. Jika digolongkan ke dalam kuadran kasus dan hospes, maka terdapat dua desa pada kuadran 1 (ada kasus dan ada hospes), satu desa pada kuadran 2 (ada kasus tapi tidak ada hospes terdeteksi), serta tiga desa di kuadran 3 ( tidak ada kasus namun ada hospes terdeteksi).

\begin{tabular}{ccc}
\hline & Kasus $(+)$ & Kasus (-) \\
\hline Reservoir $(+)$ & Trimulyo Parangtritis & Wukirsari \\
Potorono & & \\
Tirtohargo & & \\
Reservoir (-) & Bangunharjo & - \\
\hline
\end{tabular}


Kondisi wilayah yang masuk dalam kuadran 2 memiliki beberapa kemungkinan. Pertama adalah sumber penularan berasal dari tempat lain, atau keterbatasan penelitian ini dimana hanya dilakukan secara cross sectional. Sebaliknya, kondisi yang terjadi pada kuadran 3 perlu lebih diwaspadai karena potensi penularan di daerah ini sangat tinggi. Terdapat pula kemungkinan kasus yang tidak terlaporkan, terutama pada leptospirosis ringan karena gejala klinis tidak spesifik sehingga seringkali misdiagnosed atau underdiagnosed.

\section{KESIMPULAN}

Tikus sebagai reservoir utama leptospirosis ditemukan di sembilan titik pengambilan sampel. Rata-rata perolehan tikus tertinggi terdapat pada titik dekat dengan pemukiman dengan spesies paling dominan adalah R.tanezumi. Peran tikus sebagai reservoir dibuktikan dengan adanya persentase Leptospira patogenik. Persentase tertinggi justru terdapat pada R.norvegicus yang ditemukan ekosistem non-hutan dan pesisir. Berdasarkan ekosistemnya, pesisir memiliki persentase leptospira patogenik yang tertinggi dengan habitat utama adalah hutan mangrove dan spesies utama adalah R.tiomanicus. Kasus leptospirosis pada rentang periode dan lokasi penelitian hanya dilaporkan dua kasus di ekosistem non-hutan dan satu kasus di ekosistem pesisir. Terdapat tiga desa lokasi penelitian yang tidak melaporkan kasus namun terdapat reservoir yang terdeteksi sehingga perlu adanya kewaspadaan dini di wilayah tersebut.

'Daerah pemukiman merupakan daerah yang sangat rentan terjadi penularan leptospirosis karena daerah tersebut sangat padat akan populasi tikus sehingga upaya pengendalian tikus secara terpadu dan kontinyu di wilayah pemukiman sangat disarankan.

Wilayah hutan mangrove, meskipun memiliki salinitas tinggi, namun ketersediaan sumber makanan tikus terdapat terus-menerus. Konsekuensinya tikus di wilayah ini juga memiliki kepadatan yang selalu tinggi sehingga pemukiman di sekitar hutan mangrove juga perlu untuk mengantisipasi adanya invasi tikus dari hutan mangrove.

Kemampuan penemuan kasus leptospirosis pada manusia juga perlu untuk ditingkatkan mulai tingkat Puskesmas untuk menjaring kemungkinan kasus yang tidak terlaporkan.

\section{UCAPAN TERIMA KASIH}

Terima kasih kami haturkan kepada pemerintah Provinsi DIY, Dinas Kesehatan Provinsi DIY, Dinas Kesehatan Kabupaten Bantul, Bapak Jastal selaku Koordinator Lapangan Rikhus Vektora Provinsi DIY, sdr. Agung Puja Kesuma selaku Penanggung Jawab Provinsi Rikhus Vektora Provinsi DIY, tim laboratorium mikrobiologi B2P2VRP, dan rekan-rekan pengumpul data Rikhus Vektora Kabupaten Bantul.

\section{DAFTAR RUJUKAN}

1. Haake DA, Levett PN. Leptospirosis in Humans. Curr Top Microbiol Immunol. 2015;387:65-97.doi:10.1007/978-3-66245059-8.

2. Costa F, Wunder EA, Oliveira D De, Bisht V. Patterns in Leptospira Shedding in Norway Rats ( Rattus norvegicus ) from Brazilian Slum Communities at High Risk of Disease Transmission.2015:1-14. doi:10.1371/journal. pntd.0003819.

3. Lau CL, Watson $\mathrm{CH}$, Lowry $\mathrm{JH}$, et al. Human Leptospirosis Infection in Fiji: An Eco-epidemiological Approach to Identifying Risk Factors and Environmental Drivers for Transmission. PLoS Negl Trop Dis.2016;10(1):1-25.doi:10.1371/journal. pntd.0004405.

4. Mwachui MA, Crump L, Hartskeerl R, Zinsstag J, Hattendorf J. Environmental and Behavioural Determinants of Leptospirosis Transmission: A Systematic Review. PLoS Negl Trop Dis. 2015;9(9):1-15. doi:10.1371/ journal.pntd.0003843.

5. Reis MG, Childs JE, Airam V, et al. A TwoYear Ecological Study of Norway Rats (Rattus norvegicus) in a Brazilian Urban Slum. PLoS One.2016;11(3):e0152511.doi:10.1371/ journal.pone. 0152511 .

6. Villanueva S. Serologic and Molecular Studies of Leptospira and Leptospirosis among Rats in the Philippines. 2017;(May 2010). 
doi:10.4269/ajtmh.2010.09-0711.

7. Himsworth CG, Jardine CM, Parsons KL, Feng AYT, Patrick DM. The Characteristics of Wild Rat (Rattus spp.) Populations from an Inner-City Neighborhood with a Focus on Factors Critical to the Understanding of Rat-Associated Zoonoses. PLoS One. 2014;9(3):e91654.doi:10.1371/journal. pone.0091654.

8. Shiels AB. Population ecology of introduced rodents (Rattus rattus, Rattus exulans, and Mus musculus) and their habitat uses in Hawaiian mesic forest. 2010. manoa.hawaii. edu/hpicesu/DPW/AS_THESIS/AS_2010. pdf.

9. Andersen-Ranberg EU, Pipper C, Jensen PM. Global Patterns of Leptospira Prevalence in Vertebrate Reservoir Hosts . J Wildl Dis. 2016;52(3):468-477.doi:10.7589/2014-10245.

10. Harper GA, van Dinther M, Russell JC, Bunbury N. The response of black rats (Rattus rattus) to evergreen and seasonally arid habitats: Informing eradication planning on a tropical island. Biol Conserv. 2015;185:66-74. doi:10.1016/j.biocon.2014.11.044

11. Harper GA, Bunbury N. Invasive rats on tropical islands: Their population biology and impacts on native species. Glob Ecol Conserv.2015;3:607-627.doi:10.1016/j. gecco.2015.02.010.

12. Nurbeti M, Kusnanto H, Widagdo Sri Nugroho. Kasus-kasus Leptospirosis di Perbatasan Kabupaten Bantul, Sleman, dan Kulon Progo: Analisis Spasial. Kesmas Natl Public Heal J. 2016;10(1):1-14.

13. Suryani L, Pramoedyo H, Andarini S. The Biotic Environmental as Risk Factors Human Leptospirosis in Yogyakarta, Indonesia.2017;020035(2016):1-5. doi:10.1063/1.4953509.

14. Cunningham D., Moors P. GUIDE TO THE IDENTIFICATION AND COLLECTION OF NEW ZEALAND RODENTS. 2nd Editio. New Zealand: New Zealand Department of Conservation; 1993.

15. Corbet GB, Hill JE. The Mammals of the Indomalayan Region: A Sistematic Review. Oxford: Oxford University Press; 1992.

16. Ahmed N, Devi SM, Valverde MDLÁ, et al. Multilocus sequence typing method for identification and genotypic classification of pathogenic Leptospira species. BioMed Cent. 2006;5(28):1-10. doi:10.1186/1476-0711-5Received.

17. Shiels AB, Pitt WC, Sugihara RT, Gary W. Biology and Impacts of Pacific Island Invasive Species . 11. Rattus rattus, the Black Rat ( Rodentia: Muridae ). 2014;68(2):145-184. doi:10.2984/68.2.1.

18. Banks PB, Smith HM. The ecological impacts of commensal species: black rats, Rattus rattus, at the urban-bushland interface. Wildl Res. 2015;42(2):86. doi:10.1071/wr15048.

19. Feng AYT, Himsworth CG. The secret life of the city rat: A review of the ecology of urban Norway and black rats (Rattus norvegicus and Rattus rattus). Urban Ecosyst. 2014;17(1):149162. doi:10.1007/s11252-013-0305-4.

20. Ristiyanto, Wibawa T, Budiharta S, Supargiono. Prevalensi Tikus Terinfeksi Leptospira interogans. Vektora. 2015;7(2):8592.

21. Mulyono A, Handayani FD, Putro DBW, Rahardianingtyas E. Seroprevalensi Leptospira pada Rattus norvegicus dan Rattus tanezumi Berdasarkan Jenis Kelamin dan Umur. J Vektora. 2015;7(1):7-14.

22. Masuzawa T, Uchida K, Fukui $\mathrm{T}$, et al. Molecular Epidemiological Survey of Leptospira Infection of Wild Rodents in the Urban Settlement of Cambodia . VectorBorne Zoonotic Dis. 2018;18(3):144-150. doi:10.1089/vbz.2017.2198.

23. Himsworth CG, Bidulka J, Parsons KL, et al. Ecology of Leptospira interrogans in Norway Rats ( Rattus norvegicus ) in an InnerCity Neighborhood of Vancouver, Canada. 2013;7(6). doi:10.1371/journal.pntd.0002270.

24. Ikawati B, Widiastuti D. Dominant factors in fluencing leptospira sp infection in rat and suncus. Heal Sci J Indones. 2012;3(2):27-30.

25. Bar-Massada A, Radeloff VC, Stewart SI. Biotic and abiotic effects of human settlements in the wildland-urban interface. Bioscience. 2014;64(5):429-437.doi:10.1093/biosci/ biu039.

26. Hulme-Beaman A, Dobney K, Cucchi T, Searle JB. An Ecological and Evolutionary Framework for Commensalism in Anthropogenic Environments. Trends Ecol Evol. 2016;31(8):633-645. doi:10.1016/j. tree.2016.05.001. 